\title{
Comparison of Growth Hormone Receptor, IGF-1R and IGFBP-3 Between Tumoral and Non-Tumoral Areas in Non-Melanoma Skin Cancers
}

\author{
Melanositik Olmayan Deri Kanserlerinde Tümöral ve Peritümöral \\ Alanlardaki Büyüme Hormonu Reseptörü, İnsülin Benzeri Büyüme \\ Faktörü-1 Reseptörü ve İnsülin Benzeri Büyüme Faktörü Bağlayıcı \\ Protein-3'ün Karşılaştırılması
}

Özge GÜNDÜZ1', Özay GÖKÖZ², Gül ERKIN' ', Tülin AKAN'

Department of ${ }^{1}$ Dermatology and ${ }^{2}$ Pathology, Hacettepe University, Faculty of Medicine, ANKARA, TURKEY

\begin{abstract}
Objective: A relationship between the pathogenesis of some cancers and growth hormone, insulin-like growth factor-1 and insulin-like growth factors binding protein-3 has been shown. Our aim was to evaluate the expression of growth hormone receptor, insulin-like growth factor-1 receptor and insulin-like growth factors binding protein-3 in actinic keratosis, basal cell carcinoma and squamous cell carcinoma, and to compare the expression patterns of tumoral areas with normal epidermis and skin appendages.

Material and Method: The formalin-fixed, paraffin-embedded tissues of 40 patients which were diagnosed as 15 actinic keratosis, 15 basal cell carcinoma and 15 squamous cell carcinoma were analyzed for growth hormone receptor, insulin-like growth factor-1 receptor and insulin-like growth factors binding protein-3 with the immunohistochemical method using the streptavidin-biotin-peroxidase technique.

Results: There was no difference between tumoral areas of actinic keratosis, basal cell carcinoma and squamous cell carcinoma in expression of growth hormone receptor and insulin-like growth factors binding protein-3 $(\mathrm{P}>0.05)$. However, a significantly higher expression of insulin-like growth factor-1 receptor was observed in tumoral areas of squamous cell carcinoma $(\mathrm{P}<0.01)$. In basal cell carcinoma, a significantly lower intensity of immunostaining with growth hormone receptor, insulin-like growth factor-1 receptor and insulin-like growth factors binding protein-3 in tumoral areas than skin appendages was seen $(\mathrm{P}<0.01)$. In squamous cell carcinoma, higher expressions of growth hormone receptor, insulin-like growth factor-1 receptor and insulin-like growth factors binding protein-3 in tumoral areas than peritumoral epidermis was found $(\mathrm{P}=0.06, \mathrm{P}<0.01$ and $\mathrm{P}=0.02$, respectively).
\end{abstract}

Conclusion: Our study points out that, growth hormone receptor, insulin-like growth factor-1 receptor and insulin-like growth factors binding protein-3 have a role in the pathogenesis of non-melanoma skin cancers, especially squamous cell carcinoma.

Key Words: Skin neoplasms, Growth hormone, Insulin-like growth factor-1

\section{ÖZ}

Amaç: Büyüme hormonu, insülin benzeri büyüme faktörü-1 ve insülin benzeri büyüme faktörü bağlayıcı protein-3 bazı kanserlerin patogenezi ile ilişkili bulunmuştur. Aktinik keratoz, bazal hücreli karsinom veya skuamoz hücreli karsinomda büyüme hormon reseptörü, insülin benzeri büyüme faktörü-1 reseptörü ve insülin benzeri büyüme faktörü bağlayıcı protein-3 ekspresyonunun belirlenmesi ve tümöral alanların ekspresyon özelliklerinin normal epidermis ve deri ekleriyle karşılaştırılması amaçlandi.

Gereç ve Yöntem: Kurk hastaya ait formaldehitle fikse edilmiş, parafine gömülmüss aktinik keratoz $(\mathrm{n}=15)$, bazal hücreli karsinom $(\mathrm{n}=15)$ ve skuamoz hücreli karsinom $(n=15)$ tanısı almış doku örnekleri streptavidin-biotin-peroksidaz tekniği kullanılarak immünohistokimyasal metodla büyüme hormon reseptörü, insülin benzeri büyüme faktörü-1 reseptörü ve insülin benzeri büyüme faktörü bağlayıcı protein-3 varlığı açısından incelendi.

Bulgular: Çalışmamızda, aktinik keratoz, bazal hücreli karsinom ve skuamoz hücreli karsinomun tümöral alanları arasında büyüme hormon reseptörü ve insülin benzeri büyüme faktörü bağlayıcı protein-3 ekspresyonu açısından anlamlı fark bulunmazken $(\mathrm{P}>0.05)$; insülin benzeri büyüme faktörü-1 reseptörü ile skuamoz hücreli karsinomda tümöral alanlarda anlamlı olarak daha fazla ekspresyon izlendi $(\mathrm{P}<0.01)$. Bazal hücreli karsinomda büyüme hormon reseptörü, insülin benzeri büyüme faktörü-1 reseptörü ve insülin benzeri büyüme faktörü bağlayıcı protein-3 ile tümöral alanların deri eklerinden anlamlı olarak daha az şiddette boyandığ görüldü $(\mathrm{P}<0.01)$. Skuamoz hücreli karsinomda tümöral alan büyüme hormon reseptörü, insülin benzeri büyüme faktörü-1 reseptörü ve insülin benzeri büyüme faktörü bağlayıcı protein-3 ile peritümöral epidermisten daha fazla şiddette boyanma gösterdi (sırasiyla $\mathrm{P}=0.06$, $\mathrm{P}<0.01$ ve $\mathrm{P}=0.02$ ).

Sonuc: Calıșmamız büyüme hormon reseptörü, insülin benzeri büyüme faktörü-1 reseptörü ve insülin benzeri büyüme faktörü bağlayıcı protein-3'ün melanositik olmayan deri kanserlerinde ve özellikle skuamoz hücreli karsinomda patogenezde rolü bulunduğunu göstermektedir.

Anahtar Sözcükler: Deri tümörleri, Büyüme hormonu, İnsülin benzeri büyüme faktörü-1

Correspondence: Özge GÜNDÜZ

Ufuk Üniversitesi, Tip Fakültesi, Dermatoloji Anabilim Dalı,

ANKARA, TURKEY

E-mail: drozgegunduz@yahoo.com Phone: +90 3122044109 


\section{INTRODUCTION}

The skin is a target organ for growth hormone (GH) that exerts its proliferative and anabolic effects via its receptor. Growth hormone receptor (GHR) has been shown to be expressed in the epidermis (mainly in stratum basale and spinosum), adnexal structures, dermal fibroblasts, adipocytes, schwann and muscle cells $(1,2)$. GH stimulates the synthesis of insulin-like growth factor-1 (IGF-1). It is a major mediator of the effect of GH. IGF-1 has a strong influence on cell proliferation and differentiation and is a potent inhibitor of apoptosis. The action of IGF-1 is predominantly mediated by the IGF-1 receptor (IGF$1 \mathrm{R})$ that is overexpressed by many tumor cell lines. The bioavailability of IGF-1 for interaction with its receptor is modulated by insulin-like growth factor binding proteins (IGFBP 1-6), especially by IGFBP-3 (3). IGFBP-3 has antiproliferative effects through proapoptotic activities both dependent on and independent of p53 (4). Although there is no evidence that GH is produced in the skin, IGF-1 is synthesized in the skin by dermal fibroblasts, melanocytes and possibly by keratinocytes. Dermal fibroblasts are sources of IGFBP-3 (5).

There are studies showing increased incidence of gastrointestinal system cancers in acromegaly patients (6). It was also reported that elevated serum concentrations of IGF-1 increase the risk for breast, prostate, colorectal, and lung cancers (7-10). Additionally, low serum IGFBP-3 predicts increased cancer risk (11).

In previous studies, expression features of GHR and IGF$1 \mathrm{R}$ were studied in separate tissues of non-melanoma skin cancers (12-13). However, the expression patterns of GHR, IGF-1R and IGFBP-3 have not been studied in same specimens of non-melanoma skin cancers. Also, expression features of GHR, IGF-1R and IGFBP-3 have not been compared between tumoral and non-tumoral areas yet. In the present study, we aimed to evaluate the differences in expression of GHR, IGF-1R, and IGFBP-3 between actinic keratoses (AK), basal cell carcinoma (BCC), and squamous cell carcinoma (SCC) tissues and to demonstrate their role in tumorigenesis by comparing the expression patterns of tumoral areas with normal epidermis and skin appendages.

\section{MATERIAL and METHODS}

\section{Patients and Samples}

All tissues used in this study were retrieved from the archives of the Department of Pathology, Hacettepe University Faculty of Medicine. Haematoxylin-eosin-stained slides were reviewed by a pathologist, and 15 cases from each of
AK, BCC and SCC that had peritumoral normal epidermis were selected. A total number of 45 samples, which were obtained from 40 patients, were included.

\section{Immunohistochemistry}

Immunohistochemical analysis was performed on formalinfixed, paraffin-embedded tissues using the streptavidinbiotin-peroxidase technique. From each paraffin block, 3 sections were cut at $4 \mu \mathrm{m}$, and were collected on slides. Sections were deparaffinized in xylene and rehydrated by alcohol. Endogenous peroxidase activity was blocked by 10 min incubation of hydrogen peroxidase. For antigen retrieval; deparaffinized and rehydrated tissue sections were treated by pressure cooker with citrate buffer (for IGF$1 \mathrm{R}$ and IGFBP-3) and EDTA (for GHR) at full pressure for $3 \mathrm{~min}$. The antibodies against IGF-1Ra (Santa Cruz Sc-712) and IGFBP-3 (R\&D Systems MAB 305) were incubated at room temperature for 1 hour and used at $1 / 50$ and 1/100 concentrations; respectively. The antibody against GHR (Serotec MCA 1555), was used at 1/75 dilution, was incubated overnight at room temperature. After 2 washes in phosphate-buffered saline (PBS), signals were detected by the Daco Envision Method according to the manufacturers instructions. After the third washing in PBS, the specimens were incubated with $\mathrm{DAB}$ for development and counterstained with hematoxylin.

\section{Evaluation of staining}

In the immunostained slides; tumoral, perilesional normal epidermis and skin appendages, which mostly composed of hair follicles and if present sebaceous glands, were evaluated by using a double-headed light microscope at x200 and $\mathrm{x} 400$ magnification. Immunohistochemical expression was defined as the presence of cytoplasmic and/or nuclear staining similar to positive controls. The expression pattern was classified as cytoplasmic, nuclear or mixed. In an attempt to compare the tumoral tissues with non-tumoral areas, we categorized the staining intensity semiquantitatively as none (no staining), weak $(1+)$, moderate $(2+)$ or strong (3+) for each case. Specimens of liver, hypophysis and placenta were used as positive controls for GHR, IGF-1R $\alpha$ and IGFBP-3, respectively.

\section{Statistical analysis}

Statistical analysis was performed by non-parametric analyses with the Kruskal-Wallis test and Fisher-FreemanHalton test to compare the AK, BCC and SCC groups. The Cochrane-Q and pair wise Mc Nemar tests were performed to compare the tumoral and non-tumoral areas of each type of lesion. The SPSS 11.5 and 15 programs for Windows were 
used for statistical analysis. $P$ values of less than 0.05 were considered statistically significant. The statistical power of this study was calculated as $100 \%$ with the G.Power3.1.5 program.

The present study was approved by the Ethical Commitee of Hacettepe University Faculty of Medicine (LUT 06/10-44).

\section{RESULTS}

Forty-five specimens from 25 men and 15 women with an average age of $59.6( \pm 16.7)$ years were included in this study. Most of the lesions were located on head and neck region $(n=34,76 \%)$. Due to the sectioning or immunohistochemistry method; peritumoral epidermis and skin appendages were not seen in 2 and 3 specimens, respectively. In non-tumoral areas; staining with GHR showed immunoreactivity in $98 \%$ of keratinocytes $(n=42)$ and skin appendages $(n=41)$, and displayed mostly cytoplasmic and mixed patterns. Staining intensity was mostly moderate $(n=17,39 \%)$ in peritumoral epidermis and mostly strong $(\mathrm{n}=28,67 \%)$ in skin appendages. Nontumoral epidermis presented with an immunoreactivity, which was mostly weak ( $\mathrm{n}=8)$, for IGF-1Ra in $21 \%$ of $(n=9)$ the specimens. On the other hand, 95\% $(n=40)$ of skin appendages expressed IGF-1R $\alpha$ also with weak $(n=22,52 \%)$ intensity. With IGFBP-3, all specimens of non-tumoral epidermis and skin appendages showed immunoreactivity mostly with moderate or strong intensity in $86 \%(n=37)$ and 98\% $(n=41)$, respectively. All non-tumoral areas displayed striking immunoreactivity of cytoplasmic pattern with IGF-1R $\alpha$ and IGFBP-3.

Results of GHR, IBF-1R $\alpha$ and IGFBP-3 stainings are summarized in Table I. When tumoral areas of AK, BCC and SCC are compared; significantly higher number of cases showed expression with IGF-1Ra in SCC (87\%) than AK $(40 \%)$ and BCC $(20 \%)(P<0.01)$ (Figure 1). However, the percentage of positive expression with GHR and IGFBP-3 showed statistically similar expression in all tumoral areas $(P=0.31$ and $P=0.31$, respectively). In BCC $(6 / 15)$, a significant palisade-like accentuation of GHR immunostaining in the border of tumoral lobules was observed $(P<0.01)$ (Figure 2$)$.

When number of positive stainings of tumoral areas were compared with peritumoral epidermis and skin appendages, none of the tumoral areas of $\mathrm{AK}, \mathrm{BCC}$ and SCC showed difference with GHR and GFBP-3 ( $P>0.05)$. On the other hand, stainings of tumoral areas in AK and BCC showed statistically lower number of positive stainings than skin appendages with IGF- $1 \mathrm{R} \alpha(P=0.01$ and $P<0.01$, respectively). Additionally, in SCC significantly higher number of positive staining of tumoral areas than peritumoral epidermis was seen $(P=0.02)$ (Table II).

In Table III, results of staining intensity of tumoral areas were compared with peritumoral epidermis and skin appendages. In $\mathrm{AK}$, tumoral areas and peritumoral epidermis showed no difference in terms of staining intensity

Table I: Immunoexpression features of GHR, IGF-1R $a$ and IGFBP-3 in tumoral areas

\begin{tabular}{|c|c|c|c|c|c|c|}
\hline \multirow{2}{*}{ Tumoral areas } & \multirow{2}{*}{ Total \# } & \multicolumn{4}{|c|}{ Intensity of staining (n) } & \multirow{2}{*}{ Positive staining (\%) } \\
\hline & & None & Weak & Moderate & Strong & \\
\hline \multicolumn{7}{|l|}{ GHR } \\
\hline $\mathrm{AK}$ & 15 & 0 & 8 & 3 & 4 & 100 \\
\hline BCC & 15 & 2 & 1 & 6 & 6 & 87 \\
\hline SCC & 15 & 0 & 3 & 3 & 9 & 100 \\
\hline \multicolumn{7}{|l|}{$I G F-1 R \alpha^{*}$} \\
\hline $\mathrm{AK}$ & 15 & 9 & 4 & 2 & 0 & 40 \\
\hline $\mathrm{BCC}$ & 15 & 12 & 3 & 0 & 0 & 20 \\
\hline SCC & 15 & 2 & 8 & 5 & 0 & 87 \\
\hline \multicolumn{7}{|l|}{ IGFBP-3 } \\
\hline $\mathrm{AK}$ & 15 & 0 & 1 & 7 & 7 & 100 \\
\hline $\mathrm{BCC}$ & 15 & 2 & 6 & 6 & 1 & 87 \\
\hline SCC & 15 & 0 & 1 & 4 & 10 & 100 \\
\hline
\end{tabular}

${ }^{*} P<0.01$.

\#, Number; GHR, Growth hormone receptor; IGF-1Ra, Insulin-like growth factor 1 receptor alpha; IGFBP-3, Insulin-like growth factor binding protein-3; AK, Actinic keratoses; BCC, Basal cell carcinoma; SCC, Squamous cell carcinoma. 
with GHR and IGFBP-3 ( $P=0.62$ and $P=0.75$, respectively). On the other hand, with IGF-1Ra significantly similar or more intense staining in tumoral areas than peritumoral epidermis was seen $(\mathrm{P}=0.03)$. Additionally, there was statistically significant difference between expressions of GHR, IGF-1R $\alpha$ and IGFBP-3 in tumoral areas of AK and skin appendages $(P=0.01, P<0.01$ and $P=0.03$, respectively). In BCC, while immunostaining with GHR and IGF-1Ra

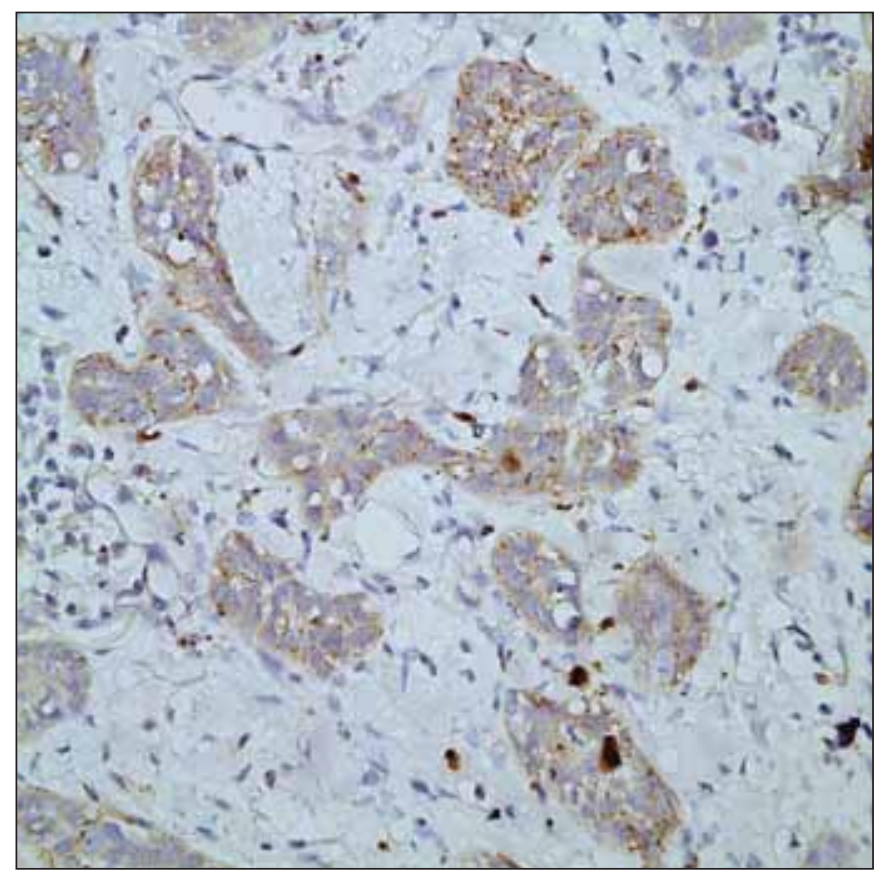

Figure 1: With IBF-1Ra, tumoral areas of SCC showed moderate immunoreactivity of cytoplasmic and granular pattern (X40). showed no difference between tumoral and peritumoral epidermis, IGFBP-3 was statistically significantly expressed lower in tumoral areas than peritumoral epidermis $(P<0.01)$. On the other hand, in BCC, significantly lower intensity of immunostaining with GHR, IGF-1R $\alpha$ and IGFBP-3 in tumoral areas than skin appendages was seen $(P<0.01)$. In SCC, higher expressions of GHR, IGF-1R $\alpha$ and IGFBP-3 in tumoral areas than peritumoral epidermis was found

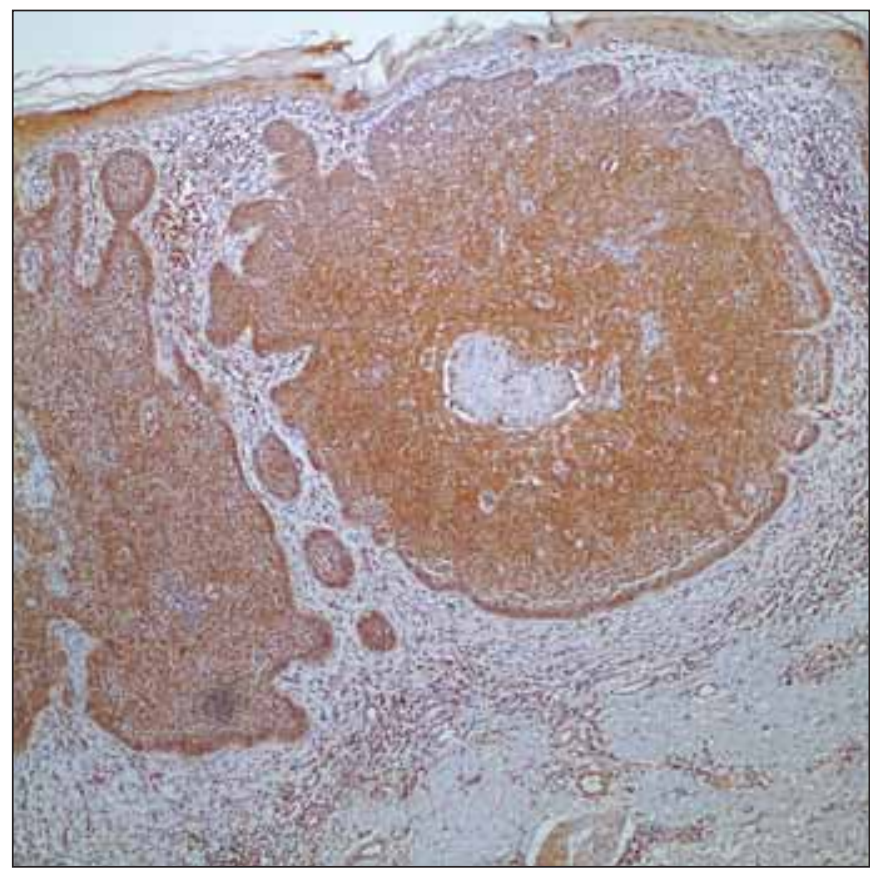

Figure 2: Accentuation of GHR immunostaining in the peripheral rim of tumoral lobules of BCC (X10).

Table II: Showing number of positive expression and comparison between tumoral and non-tumoral areas

\begin{tabular}{|c|c|c|c|c|}
\hline Antibodies & \multicolumn{3}{|c|}{ Number of positive expression } & \multirow[t]{2}{*}{$\mathbf{P}$} \\
\hline$A K$ & Tumoral areas & Epidermis & Skin app. & \\
\hline GHR & $15 / 15$ & $13 / 14$ & $13 / 13$ & \\
\hline IGF-1Ra & $6 / 15$ & $2 / 14$ & $13 / 13^{*}$ & 0.01 \\
\hline IGFBP-3 & $15 / 15$ & $14 / 14$ & $13 / 13$ & \\
\hline$B C C$ & Tumoral areas & Epidermis & Skin app. & \\
\hline GHR & $13 / 15$ & $15 / 15$ & $14 / 15$ & \\
\hline IGF-1Ra & $3 / 15$ & $3 / 15$ & $14 / 15^{*}$ & $<0.01$ \\
\hline IGFBP-3 & $13 / 15$ & $15 / 15$ & $15 / 15$ & \\
\hline$S C C$ & Tumoral areas & Epidermis & Skin app. & \\
\hline GHR & $15 / 15$ & $14 / 14$ & $14 / 14$ & \\
\hline IGF-1Ra & $13 / 15$ & $4 / 14^{*}$ & $13 / 14$ & 0.02 \\
\hline IGFBP-3 & $15 / 15$ & $14 / 14$ & $14 / 14$ & \\
\hline
\end{tabular}

*, pair of tumoral area; GHR, Growth hormone receptor; IGF-1Ra, Insulin-like growth factor 1 receptor alpha; IGFBP-3, Insulin-like growth factor binding protein-3; Skin app., Skin appendages; AK, Actinic keratoses; BCC, Basal cell carcinoma; SCC, squamous cell carcinoma. 
( $P=0.06, P<0.01$ and $P=0.02$, respectively). However, no correlation was detected in immunostaining intensities of tumoral areas and skin appendages $(P=0.41, P=, 17$ and $P$ $=1.00$, respectively).

\section{DISCUSSION}

The skin is a target organ for the GH/IGF axis. Both GH and IGF receptors have been detected in the normal skin, and cutaneous cells have shown proliferation in response to administration of GH and IGF (14). IGFBP-3 is shown to inhibit DNA synthesis and it is also able to stimulate cell death by apoptosis (15). In our study, consistent with Ginarte et al.s findings, peritumoral epidermis and skin appendages showed immunoreactivity with GHR in cytoplasmic or mixed pattern (12). Keehn and Saeed reported that epidermis was negative for IGF-IR expression, whereas skin appendages showed strong immunoreactivity (13). In our study, weak and cytoplasmic immunoreactivity with IGF-1Ra was seen in $21 \%$ of peritumoral epidermis, and $95 \%$ of skin appendages. This could be due to the choice of different brand of monoclonal antibody against IGFIR from Keehn and Saeed's study (13). Our findings with IGFBP-3 in normal epidermis are similar to Mallipeddi et al. who reported cytoplasmic panepidermal staining (16).

Hormones and growth factors are thought to facilitate the uncontrolled proliferation of transformed cells. Changes in the level of growth factors or their receptors may be important in the pathogenesis of a number of different types of tumours. For instance, GHR was significantly overexpressed in tumoral cells of colorectal and breast carcinomas (17-18). A reverse interaction between GHR expression

Table III: Comparison of staining intensity between tumoral and non-tumoral areas

\begin{tabular}{|c|c|c|c|c|}
\hline \multirow{2}{*}{$\begin{array}{l}\text { Antibodies } \\
A K\end{array}$} & \multicolumn{3}{|c|}{ Number of specimens } & \multirow[t]{2}{*}{$\mathbf{P}$} \\
\hline & Tumor >epidermis & Tumor < epidermis & Tumor =epidermis & \\
\hline GHR & 5 & 4 & 5 & 0.62 \\
\hline IGF-1Ra & 5 & 0 & 9 & 0.03 \\
\hline \multirow[t]{2}{*}{ IGFBP-3 } & 4 & 5 & 5 & 0.75 \\
\hline & Tumor $>$ skin app. & Tumor < skin app. & Tumor $=$ skin app. & \\
\hline GHR & 1 & 8 & 4 & 0.01 \\
\hline IGF-1Ra & 1 & 11 & 1 & $<0.01$ \\
\hline IGFBP-3 & 1 & 7 & 5 & 0.03 \\
\hline$B C C$ & Tumor > epidermis & Tumor < epidermis & Tumor $=$ epidermis & \\
\hline GHR & 3 & 5 & 7 & 0.36 \\
\hline IGF-1Ra & 1 & 1 & 13 & 1.00 \\
\hline \multirow[t]{2}{*}{ IGFBP-3 } & 0 & 10 & 5 & $<0.01$ \\
\hline & Tumor $>$ skin app. & Tumor < skin app. & Tumor = skin app. & \\
\hline GHR & 0 & 8 & 7 & $<0.01$ \\
\hline IGF-1Ra & 0 & 13 & 2 & $<0.01$ \\
\hline IGFBP-3 & 0 & 12 & 3 & $<0.01$ \\
\hline$S C C$ & Tumor $>$ epidermis & Tumor < epidermis & Tumor $=$ epidermis & \\
\hline GHR & 8 & 1 & 5 & 0.06 \\
\hline IGF-1Ra & 10 & 1 & 3 & $<0.01$ \\
\hline \multirow[t]{2}{*}{ IGFBP-3 } & 6 & 0 & 8 & 0.02 \\
\hline & Tumor > skin app. & Tumor < skin app. & Tumor = skin app. & \\
\hline GHR & 4 & 2 & 8 & 0.41 \\
\hline IGF-1Ra & 3 & 4 & 7 & 0.17 \\
\hline IGFBP-3 & 3 & 3 & 8 & 1.00 \\
\hline
\end{tabular}

GHR, Growth hormone receptor; IGF-1R $\boldsymbol{\alpha}$, Insulin-like growth factor 1 receptor alpha; IGFBP-3, Insulin-like growth factor binding protein-3; Skin app., Skin appendages; AK, Actinic keratoses; BCC, Basal cell carcinoma; SCC, squamous cell carcinoma. 
and stage of these cancers has been shown. In breast cancer, inhibition of IGF-1R significantly reduced metastation to lymph nodes and lung (19). It has been shown that blocking of IGF-1R with monoclonal antibodies againist IGF-1R $\left(\mathrm{aIR}_{3}\right)$ resulted in ending of cell-proliferation and enhanced cell death in melanoma cells (20). IGF-1R shows increased expression in hyperproliferative cases like psoriasis, choronic wounds and MF plaques (15). IGFBP-3 organizes bioavailability and effects of IGF-1 via binding circulating IGF-1 with high affinity. There is a relationship between IGF-1 level close to upper limit of normal range and/or IGFBP-3 level at lower limit of normal range and increased cancer risk (21). It's shown that, IGFBP-3 expression might increase for compensation in hyperproliferative lesions like psoriasis and decrease with keratinocyte differentiation (22). Moreover increased IGFBP-3 expression inhibits the keratinocyte proliferation dependently or independently to IGF-1 (23).

Stanimirovic et al. reported immunostaining with GHR in 36\% of hypertrophic AK tissues, and $80 \%$ of atrophic AK tissues $(24,25)$. They concluded that enhanced GHR expression might show elevated proliferation potential with an enhanced risk of SCC. In our study, all AK samples expressed similar immunoreactivity with GHR at tumoral areas, perilesional epidermis and skin appendages. Compared with non-tumoral areas, tumoral sites of AK did not stained intensely with GHR which might implicate that GHR do not take part in AK development. On the other hand, immunoreactivity with IGF-1Ra was seen in $40 \%$ (6/15) of tumoral sites of AK samples which were statistically stained more intensely than peritumoral epidermis $(P=0.03)$. In 11 samples of $\mathrm{AK}$, skin appendages stained more intensely than tumoral areas, consistent with higher expression feature of IGF-1Ra antibodies on skin appendages. In all AK samples (15/15), immunoreactivity was observed at tumoral and non-tumoral areas with IGFBP-3, and there was no significant difference between tumoral areas and peritumoral epidermis in terms of immunostaining intensity $(\mathrm{P}=0.75)$. Only 1 tumoral area showed significantly intense immunoexpression than skin appendages $(\mathrm{P}=0.03)$, which could be due to intensely staining feature of skin appendages with IGFBP-3. If a role of GH/IGF axis in tumorigenesis of AK is assumed, antiapoptotic effects of IGF-1 seems to be more important than GH's proliferative effects and IGFBP-3's apoptotic effects. Intense expression of IGF-1R in tumoral areas of AK samples might indicate their potential for the transformation to SCC.

Lincoln et al. reported cytoplasmic and nuclear immunoreactivity in 3 of 6 BCC tissues with GHR (26).
Ginarte et al. showed immunoreactivity in all BCC samples (7/7) with GHR (MAb263), although staining intensity of the tumoral area was weaker than normal epidermis (12). Additionally, dense immunostaining in form of palisading way that is similar to the one seen with $\mathrm{H} \& \mathrm{E}$ around tumoral lobules, was observed. In our study, immunostaining with GHR was seen in 13 of 15 BCC tissues. Only in 3 samples of BCC, tumoral area was stained more intensely than peritumoral epidermis, and none of the tumoral areas stained stronger than skin appendages $(P=0.36, P<0.01$; respectively). Nevertheless, lower staining intensity for GHR among tumoral cells of BCC than peritumoral epidermis and skin appendages disagrees with the role proposed for $\mathrm{GH}$ as an agent involved in the development of cancer. On the other hand, palisade-like accentuation of GHR immunexpression at the border of BCC lobules was found statistically significant $(\mathrm{P}<0.01)$. This might be indicating that these neoplastic cells locating at the border are in relation with the stroma through GHR and more sensitive to proliferative effects of GH. Keehn et al. didn't observe any immunoexpression in $5 \mathrm{BCC}$ samples regarding to IGF1Ra with monoclonal antibodies (Clone 24-31, Lab Vision) (13). Similar with peritumoral epidermis, there was no immunoreactivity in 12 of 15 BCC samples for antibodies against IGF-1R in our study. Skin appendages showed positive expression in 14 of 15 BCC samples $(P<0.01)$ and more intense immunoexpression than tumoral areas with IGF-1Ra antibodies. These findings could also be due to higher expression feature of IGF-1Ra antibodies on skin appendages. The lack of IGF-1R upregulation in BCC that is slowly progressive and rarely metastasizing, suggests that antiapoptotic and metastatic effects of increased IGF-1R do not take place in pathogenesis of cancer formation in BCC (19). In our study, similar with peritumoral epidermis and skin appendages, 13 of 15 BCC samples (87\%) revealed mostly weak and moderate immunostaining. Significantly, with IGFBP-3, tumoral areas showed lower staining intensity than peritumoral epidermis and skin appendages $(P<0.01)$. It was shown that overexpression of epidermal IGFBP-3 leads to an inhibition of keratinocyte proliferation (14). Consistent with these data, lower expression of IGFBP-3 might keep tumoral cells immune to antiproliferative and apoptotic effects of IGFBP-3 and help to sustain proliferative stimulus from stroma via GHR at the periphery.

In SCC, Ginarte et al. reported that all tumoral cells (7/7) had weaker immunoreactivity than normal keratinocytes with GHR [12]. Stanimirovic et al. also stated that there is immunoreactivity in 25 of 27 SCC samples and GHR expression is more intense than perilesional epidermis (27). 
All SCC samples showed immunoreactivity with GHR at tumoral areas, peritumoral epidermis and skin appendages. In 8 of 14 SCC samples, stronger staining intensity with GHR in tumoral areas than peritumoral epidermis was seen $(\mathrm{P}=0.06)$. This finding might be a sign of the fact that GHR does not take place alone in cancer formation and to demonstrate IGF-1R and IGFBP-3 expressions in the same tissue might also be critical. Ouban et al. reported immunoreactivity with IGF-1 Rb (SC-713, Santa Cruz) only in $12,9 \%$ of 31 head and neck-located SCC samples (28). Keehn and Saeed didn't observe any immunoexpression in none of 2 SCC-in situ, and 8 SCC samples regarding to IGF-1Ra with monoclonal antibodies (Clone 24-31, Lab Vision) (13). Different from previous studies, statistically significantly weak or medium intense immunoreactivity was seen at tumoral areas in $87 \%$ of SCC samples compared with peritumoral epidermis $(P=0.02)$. In our study, tumoral epidermis showed significantly stronger intensity of immunostaining than peritumoral epidermis with IGF-1Ra $(P<0.01)$. On the other hand, in SCC tumoral area showed no difference from skin appendages in terms of staining intensity and number of positive expression. Not statistically significant but enhanced expression of GHR might induce the uncontrolled proliferation of keratinocytes. Additionally, significant expression of IGF-1R triggers antiapoptotic features of IGF-1 on keratinocytes leading to SCC development. On the other hand, autocrin and/or paracrin effects of IGF-1 must be evaluated with reverse effect of IGFBP-3 that is in favor of apoptosis. Mallipeddi et al. reported that, immunohistochemical investigation of IGFBP-3 in SCC samples showed higher expression in tumoral areas than epidermis at 4 of 11 recessive distrophic epidermolysis bullosa (EB) patients, and 20 of 21 patients without EB, respectively (16). It's claimed that more agressive course of SCC in recessive distrophic EB patients can be explained with lower immunoreactivity of IGFBP-3, which has proapoptotic effects, in these patients. In all SCC samples (15/15), mostly strong immunoreactivity that was similar with peritumoral epidermis and skin appendages was seen with IGFBP-3. Similar to the study of Mallipeddi et al. in SCC, tumoral areas showed significantly either strong or equal immunostaining than peritumoral epidermis $(P=0.02)$. Only in 3 samples of SCC, higher expression than skin appendages was seen $(P=1.00)$. In SCC none of the tumoral areas stained weaker than peritumoral epidermis with IGFBP-3, concluded as a reactive situation to strengthen apoptosis contrary to the hyperproliferative status.

In immunohistochemical method, the molecules could be detected in tissue by antibody binding. Unfortunately, as a limitation, source of these molecules cannot be determined with this method. Therefore, results of this method need support with other molecular techniques like real-time polymerase chain reaction (RT-PCR). Additionally, in further studies, effects of GH, IGF- 1 and IGFBP-3 on cellular proliferation can be compared with other proliferation markers such as Ki 67.

When all findings taken into account, in BCC, no difference was seen in expression features of tumoral area and peritumoral epidermis with GHR and IGF-1Ra. Lesser staining of tumoral area than epidermis and skin appendages with IGFBP-3 may indicate the decreased apoptosis that cannot balance the uncontrolled proliferation in tumoral cells. The findings of AK did not indicate the role of GHR, IGF-1Ra and IGFBP-3 for tumoral development, on the other hand in SCC, tumoral area was more intensely stained than epidermis with GHR and IGF-1Ra. This increased expression may be a sign of neoplastic changes in tumoral cells with enhanced proliferation and an escape from apoptosis. Normal or increased IGFBP-3 immunoreactivity in SCC, could be in order to balance the cell proliferation. In conclusion, our study points out that, growth hormone and related molecules have a role in the pathogenesis of SCC. To highlight this role, there is need for further studies with other molecular techniques.

\section{CONFLICT of INTEREST}

This study was supported by Hacettepe University Research Grant.

\section{REFERENCES}

1. Slominski A, Malarkey WB, Wortsman J, Asa SL, Carlson A: Human skin expresses growth hormone but not the prolactin gene. J Lab Clin Med 2000, 136(6):476-481

2. Lobie PE, Breipohl W, Lincoln DT, Garcia-Aragon J, Waters MJ: Localization of the growth hormone receptor/binding protein in skin. J Endocrinol 1990, 126:467-471

3. Grimberg A, Cohen P: Role of insulin-like growth factors and their binding proteins in growth control and carcinogenesis. J Cell Physiol 2000, 183:1-9

4. Fürstenberger $\mathbf{G}$, Senn $\mathbf{H J}$ : Insulin-like growth factors and cancer. Lancet Oncol 2002, 3:298-302

5. Zouboulis CC: The human skin as a hormone target and an endocrine gland. Hormones 2004, 3(1):9-26

6. Jenkins PJ: Acromegaly and colon cancer. Growth Horm IGF Res 2000, 10 (Suppl A):35-36

7. Hankinson SE, Willet WC, Colditz GA, Hunter DJ, Michaud DS, Deroo B, Rosner B, Speizer FE, Pollak M: Circulating concentrations of insulin-like growth factor-I and risk of breast cancer. Lancet 1998, 351:1393-1396 
8. Chan JM, Stampfer MJ, Giovannucci E, Gann PH, Ma J, Wilkinson P, Hennekens CH, Pollak M: Plasma insulin-like growth factor-I and prostate cancer risk: A prospective study. Science 1998, 279:563-566

9. Davies M, Gupta S, Goldspink G, Winslet M: The insulinlike growth factor system and colorectal cancer: Clinical and experimental evidence. Int J Colorectal Dis 2006, 21:201-208

10. Wu X, Yu H, Amos CI, Hong WK, Spitz MR: Joint effect of insulin-like growth factors and mutagen sensitivity in lung cancer risk. Growth Horm IGF Res 2000, 10 (Suppl A):26-27

11. Giovannucci E: Insulin-like growth factor-I and binding protein-3 and risk of cancer. Horm Res 1999, 51(Suppl3):34-41

12. Ginarte M, Garcia-Caballero T, Fernandez-Redondo V, Beiras A, Toribio J: Expression of growth hormone receptor in the benign and malignant cutaneous proliferative entities. J Cutan Pathol 2000, 27:276-282

13. Keehn CA, Saeed S, Bickle K, Khalil FK, Morgan MB: Expression of insulin-like growth factor 1 receptor in primary cutaneous carcinomas. J Cutan Pathol 2004, 31:368-372

14. Edmondson SR, Thumiger SP, Werther GA, Wraight CJ: Epidermal homeostasis: The role of the growth hormone and insulin-like growth factor systems. Endocr Rev 2003, 24:737-764

15. Baxter RC, Butt AJ, Schedlich LJ, Martin JL: Antiproliferative and pro-apoptotic activities of insulin-like growth factor-binding protein-3. Growth Horm IGF Res 2000, 10 (Suppl A):10-11

16. Mallipeddi R, Wessagowit V, South AP, Robson AM, Orchard GE, Eady RA, McGrath JA: Reduced expression of insulin-like growth factor-binding protein-3 (IGFBP-3) in squamous cell carcinoma complicating recessive dystrophic epidermolysis bullosa. J Invest Dermatol 2004, 122:1302-1309

17. Yang X, Liu F, Xu Z, Chen C, Li G, Wu X, Li J: Growth hormone receptor expression in human colorectal cancer. Dig Dis Sci 2004, 49:1493-1498

18. Gebre-Medhin M, Kindblom LG, Wennbo H, Törnell J, MeisKindblom JM: Growth hormone receptor is expressed in human breast cancer. Am J Pathol 2001, 158:1217-1222
19. Dunn SE, Ehrlich M, Sharp NJ, Reiss K, Solomon G, Hawkins $R$, Baserga R, Barrett JC: A dominant negative mutant of the insulin-like growth factor-I receptor inhibits the adhesion, invasion, and metastasis of breast cancer. Cancer Res 1998, 58:3353-3361

20. Kanter-Lewensohn L, Dricu A, Wang M, Wejde J, Kiessling $\boldsymbol{R}$, Larsson $\boldsymbol{O}$ : Expression of the insulin-like growth factor-1 receptor and its anti-apoptotic effect in malignant melanoma: A potential therapeutic target. Melanoma Res 1998, 8:389-397

21. Pollak M: The question of a link between insulin-like growth factor physiology and neoplasia. Growth Horm IGF Res 2000, 10 (Suppl B):21-24

22. Wraight CJ, Edmondson SR, Fortune DW, Varigos G, Werther GA: Expression of insulin-like growth factor binding protein-3 (IGFBP-3) in the psoriatic lesion. J Invest Dermatol 1997, 108:452-456

23. Edmondson SR, Thumiger SP, Kaur P, Loh B, Koelmeyer R, Li A, Silha JV, Murphy LJ, Wraight CJ, Werther GA: Insulin-like growth factor binding protein-3 (IGFBP-3) localizes to and modulates proliferative epidermal keratinocytes in vivo. $\mathrm{Br} \mathrm{J}$ Dermatol 2005, 152:225-230

24. Stanimirovic A, Cupic H, Bosnjak B, Kruslin B, Belicza M: Expression of p53, bcl-2 and growth hormone receptor in actinic keratosis, hypertrophic type. Arch Dermatol Res 2003, 295:102108

25. Stanimirovic A, Cupic H, Bosnjak B, Tomas D, Balicevic D, Kruslin B, Belicza M: Expression of p53, bcl-2 and growth hormone receptor in atrophic type of actinic keratosis. J Dermatol Sci 2004, 34:49-53

26. Lincoln DT, Sinowatz F, Temmim-Baker L, Baker HI, Kölle S, Waters MJ: Growth hormone receptor expression in the nucleus and cytoplasm of normal and neoplastic cells. Histochem Cell Biol 1998, 109:141-159

27. Stanimirovic A, Cupic H, Bosnjak B, Tomas D, Kruslin B, Belicza M: TP53, Bcl-2 and growth hormone receptor expression in cutaneous squamous cell carcinoma. Acta Dermatovenerol Croat 2005,13:201-205

28. Ouban A, Muraca P, Yeatman T, Coppola D: Expression and distribution of insulin-like growth factor-1 receptor in human carcinomas. Hum Pathol 2003, 34:803-808 